\title{
Antioxidant defences in the microaerophilic protozoan Trichomonas vaginalis: comparison of metronidazole-resistant and sensitive strains
}

\author{
Jayne E. Ellis, ${ }^{1}$ Nigel Yarlett, ${ }^{2}$ Deborah Cole, ${ }^{1}$ Michelle J. Humphreys ${ }^{1}$ and \\ David Lloyd ${ }^{1}$
}

Author for correspondence: David Lloyd. Tel: +44222 874772. Fax: +44222 874305.

\footnotetext{
1 Microbiology Group, School of Pure and Applied Biology, University of Wales College of Cardiff, PO Box 915, Cardiff CF1 3TL, UK

2 Haskins Laboratories, Pace University, New York, NY 10038, USA
}

\begin{abstract}
The sensitivity of the microaerophilic protozoan Trichomonas vaginalis to oxygen and products of its reduction, and the antioxidant defences employed by this organism, were investigated. Studies revealed that this amitochondrial flagellate is sensitive to oxygen tensions above those experienced in situ in the vagina (i.e. $>60 \mu \mathrm{M}$ ) and that metronidazole-resistant strains (CDC 85 and IR78) were more sensitive to elevated oxygen levels than a metronidazolesensitive isolate (1910). In the presence of radical scavengers, inactivation of organisms at $60 \mu \mathrm{M}$ oxygen was significantly lessened. Investigation of the antioxidant enzymes present in this organism revealed that activities of peroxide-reducing enzymes (e.g. catalase and general peroxidase) were not detectable, but that a cyanide-insensitive, azide-sensitive superoxide dismutase was present in cell extracts. Measurement of thiol-cycling enzymes indicated that NADPH could drive the reduction of oxidized glutathione (thiol reductase); however, the corresponding peroxidase activity was not detected. Analysis of thiols in whole cells of $T$. vaginalis indicated that glutathione was absent, but high levels of other thiols, propanethiol, methanethiol and $\mathrm{H}_{2} \mathrm{~S}$, were present. No significant differences were detected in thiol levels or antioxidant enzyme activities on comparison of metronidazole-sensitive and resistant strains. These results indicate that the sensitivity of $T$. vaginalis to oxygen above physiological levels is due to the lack of adequate peroxidereducing enzymes and radical-scavenging mechanisms.
\end{abstract}

Keywords: Trichomonas vaginalis, oxygen free radicals, superoxide dismutase, thiol-cycling enzymes, glutathione

\section{INTRODUCTION}

The microaerophilic protozoan parasite Trichomonas vaginalis possesses many characteristics of anaerobic organisms, including sensitivity to oxygen. In vivo, $T$. vaginalis is exposed to an environment of fluctuating nutrient levels and oxygen concentrations; measurements at the vaginal epithelium indicate that this is a microaerobic environment (Wagner \& Levin, 1978; Rashad et al., 1992). The fermentative metabolism of this organism is sensitive to oxygen fluctuations in this range (Paget \&

Abbreviations: $D A B C O$, 1,4-diazabicyclo[2.2.2]octane; PFOR, pyruvate: ferredoxin oxidoreductase; SOD, superoxide dismutase; POD, peroxidase.
Lloyd, 1990; Ellis et al., 1992). However, the mechanisms of cellular protection against potentially cytotoxic oxygen metabolites have hardly been studied in this organism, although drugs generating oxygen radicals are used for chemotherapy of trichomoniasis (Moreno \& Docampo, 1985; Docampo, 1990). This has important implications for $T$. vaginalis, where metronidazole-resistant isolates have defective oxygen-scavenging mechanisms (Lloyd \& Pedersen, 1985; Yarlett et al., 1986).

Oxidant stress is associated with the generation of reactive oxygen-derived species which are ultimately responsible for damage to a wide variety of cellular components (enzymes, DNA, membrane lipids, etc.). All living cells are prone to the toxic effects of oxygen and its reduction 
products. Adequate defence against oxidative stress usually requires the presence of a number of protective mechanisms, including the detoxifying enzymes catalase, superoxide dismutase (SOD), general peroxidase (POD) and the glutathione-cycling enzymes (Halliwell \& Gutteridge, 1989). Factors predisposing to oxygen sensitivity include inadequate oxygen-detoxifying enzymes, the presence of oxygen-sensitive enzymes central to the metabolism of the cell, lack of cellular reducing power and a high oxygen consumption rate (Morris, 1979).

T. vaginalis avidly consumes oxygen at low levels (Lloyd $t$ t al., 1989) and oxygen consumption systems are present in the cytosol (Thong \& Coombs, 1987; Linstead \& Bradley, 1988), and in the hydrogenosomes (Čerkasov et al., 1978; Müller \& Lindmark, 1978; Lloyd et al., 1983). The compartmentation of the oxygen labile-enzymes pyruvate: ferredoxin oxidoreductase (PFOR) and hydrogenase within the hydrogenosome may provide some protection from oxygen and its reduction products. Defence mechanisms operating in $T$. vaginalis agains: oxygen and products of its reduction (e.g. hydrogen peroxide, superoxide, singlet oxygen, hydroxyl radical! have not been studied in detail, although there has been a. report of the presence of SOD (Müller, 1990).

In this study we identified antioxidant enzymes in metronidazole-resistant and sensitive strains of $T$. vaginalis, and the sensitivity of this organism to oxygen. We propose that cytosolic and hydrogenosomal oxidases and SOD form major defences; however, sensitivity of this human pathogen to oxygen levels above those experienced in situ may be due to deficiencies in peroxidereducing enzymes and the generation of toxic radicals which are quenched in the presence of exogenous radical scavengers.

\section{METHODS}

Organisms. T. vaginalis strains 1910, NYH-286 (ATCC 50148), C1-NIH (ATCC 30001), RU-393 (ATCC 50142), IR78 (ATCC 50138) and CDC 85 (ATCC 50143) were cultured in TYM medium ( $\mathrm{pH} 6.2$ ), without agar, supplemented with $10 \%(\mathrm{v} / \mathrm{v})$ heat-inactivated horse serum (Diamond, 1957). Reducing agents (cysteine and ascorbate) were omitted from the growth medium for 1910, IR78 and CDC 85 cultures which were used in oxygen susceptibility and enzyme studies. The in vitro MIC for metronidazole required by the strains determined from previous studies indicated that 1910, C1-NIH and NYH 286 were metronidazole-sensitive (Yarlett et al., 1986; Ellis et al., 1992) and that IR78, CDC 85 and RU 393 were metronidazoleresistant (Müller et al., 1980; Yarlett et al., 1986). Stock cultures $(10 \mathrm{ml})$ were maintained at $37^{\circ} \mathrm{C}$ and subcultured daily. When required, $500 \mathrm{ml}$ cultures were grown to late exponential phase, harvested by centrifugation ( $500 \mathrm{~g}$ for $5 \mathrm{~min}$ ) and washed twice in Doran's buffer $\left(\mathrm{KCl}, 16 \mathrm{mM} ; \mathrm{CaCl}_{2}, 6 \mathrm{mM} ; \mathrm{NaCl}, 75 \mathrm{mM}\right.$; $\mathrm{NaH}_{2} \mathrm{PO}_{4} \cdot 3 \mathrm{H}_{2} \mathrm{O}, 30 \mathrm{mM} ; \mathrm{pH} 7 \cdot 0$ ) (Doran, 1969). This was prepared using distilled water rendered oxygen-free by boiling and cooling under nitrogen. Cell-free extracts were obtained by resuspending the final washed pellet in breakage buffer $(225 \mathrm{mM}$ sucrose, $20 \mathrm{mM} \mathrm{KCl}, 5 \mathrm{mM} \mathrm{MgCl}_{2}, 1 \mathrm{mM}$ EDTA, $20 \mathrm{mM}$ Tris $/ \mathrm{HCl}, 10 \mathrm{mM}$ potassium phosphate; $\mathrm{pH} 7 \cdot 0$ ) and disruption of the organisms by three cycles of freezing in liquid nitrogen and thawing. Homogenates were kept in sealed tubes under nitrogen at $4^{\circ} \mathrm{C}$ and assayed immediately. Anaerobic precautions were maintained throughout. Organisms were counted using a haemacytometer.

Oxygen electrode. A Clark-type oxygen electrode open for gas exchange (Lloyd et al., 1989; Ellis et al., 1989) was used to measure the oxygen affinity of strain 1910 and the survival of three strains of $T$. vaginalis (1910, CDC 85 and IR78) in the presence of oxygen. The incubation volume was $5.5 \mathrm{ml}$ and the cell suspension was stirred at 790 r.p.m. Washed suspensions of T. vaginalis $\left(4-5 \times 10^{6} \mathrm{ml}^{-1}\right)$ were maintained at defined dissolved oxygen levels (within the range $0-220 \mu \mathrm{M}$ ) for $4 \mathrm{~h}$ at $37^{\circ} \mathrm{C}$ in the presence or absence of D-glucose $(30 \mathrm{mM})$. Samples $(50 \mu \mathrm{l})$ were removed every $20 \mathrm{~min}$ and the motility observed microscopically as a measure of cell viability. The effects of scavengers of oxygen metabolites on the survival of $T$. vaginalis were also determined by maintaining organisms at $60 \mu \mathrm{M}$ oxygen and supplementing the incubation buffer with one of the following: mannitol $(50 \mathrm{mM})$, histidine $(10 \mathrm{mM})$, DABCO $(1 \mathrm{mM})$, sodium benzoate $(10 \mathrm{mM})$ or catalase $\left(2000\right.$ units $\left.\mathrm{ml}^{-1}\right)$. All experiments were repeated at least twice.

Enzyme assays. Spectrophotometric assays were performed at $37^{\circ} \mathrm{C}$. SOD activity was measured by the method of McCord \& Fridovich (1969) using bovine SOD (Sigma) as standard. To characterize the type of metal centre present in this enzyme, the extracts were incubated for $1 \mathrm{~h}$ at $37^{\circ} \mathrm{C}$ with one of the following: $\mathrm{KCN}(1 \mathrm{mM}), \mathrm{NaN}_{3}(5 \mathrm{mM})$ or $\mathrm{H}_{2} \mathrm{O}_{2}(0.5 \mathrm{mM})$ and then assayed (Tannich et al., 1991). Non-specific peroxidase activity was assayed by the method of George (1953) and catalase as described by Cohen et al. (1970). The presence of the broad-spectrum thiol-cycling enzyme (XSSX) reductase and peroxidase were determined as described by Bergmeyer et al. (1974) and Lawrence \& Burk (1976). One unit of enzyme activity corresponds to $1.0 \mu \mathrm{mol}$ product formed or substrate catabolized $\mathrm{min}^{-1}$. Protein was estimated by the method of Bradford (1976).

Analysis of reduced thiols. Triplicate samples of $10^{6}$ cells were pelleted in $2 \mathrm{ml}$ microfuge tubes $(10000 \mathrm{~g}$, for $2 \mathrm{~min}$ ). The supernatant was carefully removed and the cell pellet was immediately resuspended in $50 \mu \mathrm{l} 40 \mathrm{mM} \mathrm{HEPPS} / \mathrm{NaOH}$, $2 \mathrm{mM}$ EDTA, $\mathrm{pH} 8 \cdot 0$. Thiols were derivatized by the addition of $2 \mathrm{mM}$ monobromobimane (Thiolyte, Calbiochem) in absolute ethanol $(50 \mu \mathrm{l})$ and heated at $70^{\circ} \mathrm{C}$ for $30 \mathrm{~min}$. After cooling, the samples were deproteinized with $4 \mathrm{M}$ methanesulphonic acid ( $\mathrm{pH} 1.5$ with $\mathrm{LiOH}$ ). After standing for $15 \mathrm{~min}$ at $4{ }^{\circ} \mathrm{C}$, derivatized protein was removed by centrifugation $(10000 \mathrm{~g}, 2 \mathrm{~min})$ and the supernatant removed for analysis by HPLC. Thiols were separated by reverse-phase HPLC on a Beckman/Altex C-18 column $(4.5 \times 250 \mathrm{~mm}$; particle size $5 \mu \mathrm{m})$ (Beckman Instruments) using a Perkin-Elmer Series 410 (North America Instrument Division) fitted with a Rheodyne loop $(10 \mu \mathrm{l})$ injector. The HPLC separation method was as described by Fairlamb et al. (1987) and consisted of solvents A [0.25\% (w/v) D-camphor sulphonate (Calbiochem), $\mathrm{pH} 2 \cdot 64]$ and $\mathrm{B}$ $[0.25 \%(\mathrm{w} / \mathrm{v})$ D-camphor sulphonate containing $25 \% n$ propanol (Calbiochem)]. Thiols were eluted using a flow rate of $1 \mathrm{ml} \mathrm{min}{ }^{-1}$ starting with an isocratic step at $10 \% \mathrm{~B}$ for $20 \mathrm{~min}$ followed by a linear gradient to $50 \% \mathrm{~B}$ for $40 \mathrm{~min}$ and then an isocratic step at $50 \% \mathrm{~B}$ for $10 \mathrm{~min}$. Starting conditions were regenerated in $5 \mathrm{~min}$ and maintained for a further $15 \mathrm{~min}$ prior to the next injection. Fluorescent compounds were detected using a Perkin-Elmer LS-1 fluorescence detector fitted with a $1 \mu \mathrm{l}$ flow cell, using an extinction wavelength of $375 \mathrm{~nm}$ and an emission wavelength of $480 \mathrm{~nm}$. Monobromobimane standards of glutathione, propanethiol, methanethiol (Aldrich) and $\mathrm{H}_{2} \mathrm{~S}$ were prepared as described for the samples. 


\section{RESULTS}

\section{Enzyme activities in cell-free extracts}

Homogenates of T. vaginalis strains 1910, IR78 and CDC 85 were assayed for antioxidant enzymes. Neither catalase nor non-specific peroxidase activities were detectable [limit of detection about $5 \mathrm{mU}(\mathrm{mg} \text { protein })^{-1}$ ]. SOD activity was present in all strains (Table 1). This enzyme was inhibited by $\mathrm{H}_{2} \mathrm{O}_{2}$ and $\mathrm{NaN}_{3}$, but not by $\mathrm{KCN}$, indicating that the activity was probably due to the presence of FeSOD. The extent of inhibition by azide varied between strains. Measurement of thiol-cycling enzymes indicated that NADPH-driven reduction of glutathione occurred. The corresponding peroxidase activity was not detectable.

\section{Survival of $T$. vaginalis in the presence of oxygen}

Washed whole-cell suspensions of T. vaginalis 1910, IR78 and $\mathrm{CDC} 85$ were maintained without the addition of $\mathrm{D}$ -

Table 1. Superoxide dismutase and thiol-reductase activities in cell-free extracts of $T$. vaginalis

\begin{tabular}{|c|c|c|c|c|c|}
\hline \multirow[t]{2}{*}{ Strain } & \multirow{2}{*}{$\begin{array}{c}\text { Thiol } \\
\text { reductase } \\
{[\mathrm{mU}(\mathrm{mg}} \\
\left.\text { protein }^{-1}\right]\end{array}$} & \multirow{2}{*}{$\begin{array}{c}\text { Superoxide } \\
\text { dismutase* } \\
{[\mathrm{U}(\mathrm{mg}} \\
\left.\text { protein })^{-1}\right]\end{array}$} & \multicolumn{3}{|c|}{$\begin{array}{l}\text { Inhibition of SOD } \\
(\%) \text { by }\end{array}$} \\
\hline & & & $\mathbf{K C N}$ & $\mathrm{NaN}_{3}$ & $\mathrm{H}_{2} \mathrm{O}_{2}$ \\
\hline 1910 & $66 \pm 15$ & $2.7 \pm 0.6$ & 0 & 10 & 70 \\
\hline IR78 & $45 \pm 9$ & $3 \cdot 4 \pm 0 \cdot 4$ & 0 & 30 & 70 \\
\hline $\operatorname{CDC} 85$ & $10 \pm 4$ & $6 \cdot 3 \pm 1 \cdot 1$ & 0 & 48 & 74 \\
\hline
\end{tabular}

* SOD cnzyme activity is defined as the amount of enzyme required to inhibit the reduction of cytochrome $c$ by $50 \%$.

Results presented are means \pm sD from three separate experiments.

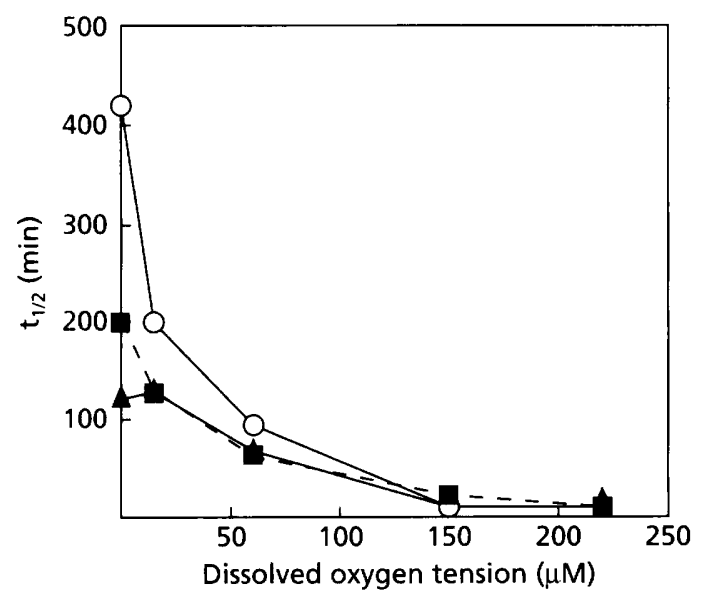

Fig. 1. Survival of washed suspensions of metronidazolesensitive (1910) and resistant (CDC 85 and IR78) strains of $T$. vaginalis $\left(4-5 \times 10^{6} \mathrm{ml}^{-1}\right)$ in the presence of dissolved oxygen. Results presented are means from at least two separate incubations. $O$, Strain 1910; $\boldsymbol{A}$, strain IR78; $\boldsymbol{\square}$, strain CDC 85; $t_{1}$, the time taken for $50 \%$ of the organisms to become nonviable.
Table 2. Effects of D-glucose and exogenous oxygen metabolite scavengers on the survival of metronidazoleresistant and sensitive strains of $T$. vaginalis at $60 \mu \mathrm{M}$ oxygen

Incubations contained 4-5 $\times 10^{6}$ organisms $\mathrm{ml}^{-1}$. Results presented are mean values from at least duplicate incubations.

\begin{tabular}{|lrrr|}
\hline \multirow{2}{*}{ Addition } & \multicolumn{3}{|c|}{$\boldsymbol{t}_{\frac{1}{2}}(\mathbf{m i n}) *$} \\
\cline { 2 - 4 } & $\mathbf{1 9 1 0}$ & IR78 & CDC 85 \\
\hline None (control) & 92 & 68 & 61 \\
D-Glucose & 227 & 149 & 340 \\
Catalase & 97 & 59 & 107 \\
DABCO & 82 & 78 & 107 \\
Histidine & 120 & 92 & 93 \\
Benzoate & 154 & 151 & 129 \\
Mannitol & 240 & 109 & 162 \\
\hline
\end{tabular}

* Time taken for $50 \%$ organisms to become non-viable.

Table 3. Thiols in $T$. vaginalis isolates

Values are expressed as $\mathrm{nmol}\left(10^{6} \text { organisms }\right)^{-1} \pm \mathrm{SD}$ from triplicate determinations. Glutathione was undetectable, limits of detection $0 \cdot 1 \mathrm{nmol}\left(10^{6} \text { organisms }\right)^{-1}$. Metronidazole-resistant isolates are RU 393, IR78 and CDC 85.

\begin{tabular}{|lcll|}
\hline Strain & Propanethiol & Methanethiol & $\mathbf{H}_{\mathbf{2}} \mathbf{S}$ \\
\hline C1-NIH & $3 \cdot 60 \pm 0 \cdot 98$ & $0 \cdot 91 \pm 0 \cdot 12$ & $3 \cdot 40 \pm 1 \cdot 4$ \\
NYH 286 & $3 \cdot 10 \pm 0 \cdot 87$ & $1 \cdot 20 \pm 0 \cdot 22$ & $4 \cdot 10 \pm 0 \cdot 9$ \\
IR78 & $2 \cdot 70 \pm 0 \cdot 80$ & $0 \cdot 65 \pm 0 \cdot 12$ & $0 \cdot 60 \pm 0 \cdot 07$ \\
CDC 85 & $2 \cdot 19 \pm 0 \cdot 96$ & $0 \cdot 75 \pm 0 \cdot 42$ & $0 \cdot 50 \pm 0 \cdot 05$ \\
RU 393 & $3 \cdot 64 \pm 1 \cdot 15$ & $0 \cdot 75 \pm 0 \cdot 05$ & $1 \cdot 20 \pm 0 \cdot 35$ \\
\hline
\end{tabular}

glucose at defined oxygen concentrations. Inactivation rates were measured at half times for loss of viability. All organisms tested retained full motility for at least $2 \mathrm{~h}$ at $<15 \mu \mathrm{M}$ oxygen (Fig. 1), whereas higher dissolved oxygen levels led to diminished viability. Average values for the time taken for $50 \%$ of the organisms to be nonviable $\left(t_{\frac{1}{2}}\right)$ revealed that the metronidazole-resistant isolates (IR78 and CDC 85) were inactivated at lower oxygen levels than the sensitive strain 1910. Addition of D-glucose $(30 \mathrm{mM})$ sustained the viabilities of all three strains at $60 \mu \mathrm{M}$ (Table 2). Addition of oxygen-metabolite scavengers also increased the duration of cell viability under these conditions (Table 2). The most pronounced effects were observed with benzoate or mannitol.

\section{Thiol analysis of $T$. vaginalis isolates}

Glutathione was not consistently detectable in whole-cell extracts of T. vaginalis by HPLC (Table 3 ). A minor signal occasionally appeared at the same retention time as glutathione in some samples (Fig. 2), but this was not consistent and probably originated from the growth medium. Significant amounts of other thiols, 

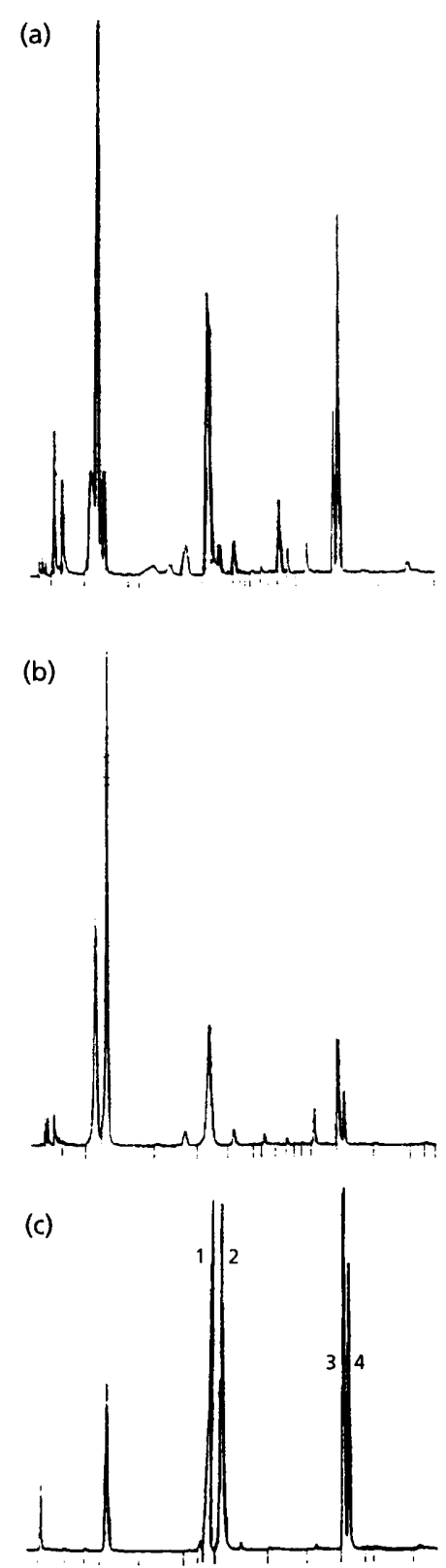

Fig. 2. HPLC analysis of $T$. vaginalis thiols. (a) $T$. vaginalis $\mathrm{C}-1$ NIH ( $10^{6}$ organisms); (b) $T$. vaginalis IR78 $\left(10^{6}\right.$ organisms); (c) standards: 1 , propanethiol $(0.35 \mathrm{nmol})$ retention time $31.6 \mathrm{mir}$; 2 , glutathione $(0.3 \mathrm{nmol})$ retention time $39.4 \mathrm{~min}$; 3 , methanethiol $(0.35 \mathrm{nmol})$ retention time $34.9 \mathrm{~min} ; 4, \mathrm{H}_{2} \mathrm{~S}$ $(0.35 \mathrm{nmol})$ retention time $54.31 \mathrm{~min}$. Thiols were separated as described in Methods.

propanethiol, methanethiol and $\mathrm{H}_{2} \mathrm{~S}$, were detected in these organisms. The relative amounts of thiols did not appear significantly different in metronidazole-resistant and sensitive strains (Table 3 ).

\section{DISCUSSION}

$T$. vaginalis copes well with oxidative stress at the low levels which are reflective of the vagina. However, at levels exceeding these (i.e. $>60 \mu \mathrm{M}$ ) this organism becomes rapidly non-viable, indicating that the parasite is well adapted to those levels encountered in situ, but less able to cope above physiological oxygen tensions. The mechanisms leading to cell inactivation during oxidative stress are complex, and in this study we attempted to identify protective mechanisms employed by this parasite and propose shortcomings that may ultimately lead to cellular damage and death.

T. vaginalis possesses protective enzymes such as SOD and NADH oxidases (Linstead \& Bradley, 1988; Ellis et al., 1992), but lacks the major peroxide-reducing enzymes catalase and general peroxidase. The SOD activity detected was an order of magnitude lower than that in the cattle parasite Tritrichomonas foetus (Lindmark \& Müller, 1974; Kitchener et al., 1984). Inhibition of SOD activity by $\mathrm{H}_{2} \mathrm{O}_{2}$, and to a lesser extent azide, suggests the presence of FeSOD in T. vaginalis, which is characteristic of other parasitic protozoa such as Entamoeba bistolytica (Tannich et al., 1991), the trypanosomatids (Meshnick \& Eaton, 1983; Trang et al., 1983) and T. foetus (Lindmark \& Müller, 1974; Kitchener et al., 1984). This enzyme has been identified as a potential chemotherapeutic target in these parasites, as FeSOD enzymes are absent in mammalian cells (Meshnick \& Eaton, 1983).

The presence of glutathione reductase activity suggested that some thiol-cycling detoxification mechanisms may operate in T. vaginalis, but glutathione peroxidase activity was absent. $T$. vaginalis, however, does not contain detectable glutathione; instead high levels of other thiols, propanethiol, methanethiol and $\mathrm{H}_{2} \mathrm{~S}$ are present. Thus, the thiol-peroxidase activity of $T$. vaginalis may be specific for a particular thiol and unable to operate with glutathione as substrate. Typical aerobic cells contain high levels of low molecular mass thiols, usually glutathione, which form a key detoxification mechanism and also protect enzymes bearing - SH groups which are considered obvious targets for oxygen attack. Other amitochondrial eukaryotes such as Giardia duodenalis and E. histolytica also lack detectable glutathione (Brown et al., 1993; Fahey et al., 1984), and thiols other than glutathione have been proposed to function in detoxification reactions in $G$. duodenalis, where cysteine is the major low molecular mass thiol (Brown et al., 1993), and in trypanosomatids, where the glutathione-conjugate trypanothione functions in a unique detoxification reaction (Smith et al., 1991). Thus, T. vaginalis may utilize low molecular mass thiols other than glutathione in the detoxification of oxygen reduction products.

Externally added scavengers of oxygen metabolites prolonged the survival of T. vaginalis in the presence of $60 \mu \mathrm{M}$ oxygen. Most effective were the radical scavengers benzoate and mannitol (Halliwell \& Gutteridge, 1989), suggesting that hydroxyl radical is formed. In the presence of intracellular oxygen, toxic metabolites can be formed from growth medium components (Morris, 1979). In the case of $T$. vaginalis, high levels of iron are present in the culture medium. The catalytic role of transition metals, particularly iron and copper, has been implicated in the catalysis of free radical reactions (Halliwell \& Gutteridge, 
1989). Traces of redox-active, non-protein-bound and soluble iron or copper catalyse the transformation of the moderately inactive superoxide radical anion $\left(\mathrm{O}_{2}^{-}\right)$to the highly active hydroxyl radical $\left(\mathrm{OH}^{\circ}\right)$ via the Haber-Weiss reaction. Under physiological conditions these metal ions are complexed to low and high molecular mass cellular components and thus serve as catalytic centres for the repeated formation of free radicals. Similarly, the presence of high levels of thiols in T. vaginalis may have detrimental effects at elevated oxygen levels. High levels of thiols, most notably thioglycollate, markedly enhanced the bactericidal effect of oxygen on moderately anaerobic bacteria (Griffiths \& Shoesmith, 1977). Thus at elevated oxygen tensions, these oxygen-scavenging molecules may generate toxic products.

The presence of high levels of exogenous D-glucose markedly enhances the oxygen tolerance of $T$. vaginalis. Indeed, many anaerobes have improved tolerance to oxygen under 'reducing' conditions (Morris, 1979). It is proposed that damage from oxygen metabolites is minimized when oxygen is utilized as a terminal electron acceptor and internal redox couples are kept fully reduced, thereby minimizing potentially harmful effects on other aspects of metabolism. The hydrogenosomal terminal oxidase of $T$. vaginalis has a high affinity for oxygen (Lloyd et al., 1982), which is somewhat surprising as it is noncytochrome and a high affinity for oxygen is not characteristic of flavoprotein oxidases (Lloyd \& Edwards, 1978; Lloyd \& Coombs, 1989). Metronidazole-resistant strains of $T$. vaginalis were inactivated more rapidly than the sensitive strain at oxygen levels characteristic of those encountered in situ in the vagina. The affinity of the hydrogenosomal oxygen consumption system of these strains for oxygen was fourfold lower than that for metronidazole-sensitive isolates (Yarlett et al., 1986). Thus for any given extracellular oxygen concentration within the range $0-20 \mu \mathrm{M}$, the corresponding intracellular oxygen concentration will be higher in the metronidazoleresistant strains than the sensitive strains, as the former have defective oxygen-scavenging systems. This is the most likely explanation for their diminished oxygen tolerance. It also accounts for the directly demonstrated enhanced metronidazole nitro radical anion quenching demonstrated in vivo by oxygen in the resistant strains (Lloyd \& Pedersen, 1985). Antioxidant enzymes such as SOD were present in these isolates at levels similar to that of the sensitive strain, as were the cytosolic oxidase activities previously reported (Ellis et al., 1992). This suggests that the oxygen protection mechanisms in metronidazole-resistant $T$. vaginalis are not as efficient as those operating in the sensitive strain, as resistant isolates are more susceptible to oxidative damage at physiological levels, and indicates that the hydrogenosomal oxidase plays a major role in the protection of $T$. vaginalis from the toxic effects of oxygen at those levels encountered in the vagina.

In summary, the survival of $T$. vaginalis in the presence of oxygen is dependent on the delicate balance of oxidant stress and defence mechanisms. Clearly, very low levels of oxygen $(<0.25 \mu \mathrm{M})$ stimulate growth of this pathogen
(Paget \& Lloyd, 1990), but the ability to deal with oxidative stress deteriorates at elevated oxygen levels. As with all cells, the aetiology of oxygen toxicity is multifactoral. Protective enzymes such as NAD $(\mathrm{P}) \mathrm{H}$ oxidases and SOD, the rapid consumption of oxygen by the hydrogenosomal oxidase, and scavenging by cellular thiols most probably keep intracellular toxic oxygen radicals at low levels in situ in the vagina. At elevated oxygen $(>60 \mu \mathrm{M})$ however, the generation of harmful oxygen metabolites probably exceeds the rate of detoxification and thus results in irreversible cellular damage and cell death.

\section{ACKNOWLEDGEMENTS}

This work was supported by the Wellcome Trust and in part by the National Institutes of Health grant A1 25361 (NY).

\section{REFERENCES}

Bergmeyer, H. U., Gawehn, K. \& Grassl, M. (1974). Enzymes as biochemical reagents. Methods Enzyme Anal 1, 425-522.

Bradford, M. M. (1976). A rapid and sensitive method for the quantitation of microgram quantities of protein using the principle of dye-binding. Anal Biochem 72, 248-254.

Brown, D. M., Upcroft, J. A. \& Upcroft, P. (1993). Cysteine is the major low molecular weight thiol in Giardia duodenalis. Mol Biochem Parasitol 61, 155-158.

Čerkasov, J., Čerkasovová, A., Kulda, J. \& Vilhelmová, D. (1978). Respiration of hydrogenosomes of Tritrichomonas foetus. I. ADPdependent oxidation of malate and pyruvate. $J$ Biol Chem 253, 1207-1214.

Cohen, G., Dembiec, D. \& Marcus, J. (1970). Measurement of catalase activity in tissue extracts. Anal Biochem 34, 30-38.

Diamond, L. S. (1957). The establishment of various trichomonads of animals and man in axenic cultures. $J$ Parasitol 43, 488-490.

Docampo, R. (1990). Sensitivity of parasites to free radical damage by antiparasitic drugs. Chem-Biol Interact 73, 1-27.

Doran, D. J. (1959). Studies on trichomonads. III. Inhibitors, acid production and substrate utilization by four strains of Tritrichomonas foetus. J Protozol 6, 177-182.

Ellis, J. E., Williams, A. G. \& Lloyd, D. (1989). Oxygen consumption by ruminal microorganisms: protozoal and bacterial contributions. Appl Environ Microbiol 55, 2583-2587.

Ellis, J. E., Cole, D. \& Lloyd, D. (1992). Influence of oxygen on the fermentative metabolism of metronidazole-sensitive and resistant strains of Trichomonas vaginalis. Mol Biochem Parasitol 56, 79-88.

Fahey, R. C., Newton, G. L., Arrick, B., Overdank-Bogart, T. \& Aley, S. B. (1984). Entamoeba histolyica: a eukaryote without glutathione metabolism. Science 224, 70-72.

Fairlamb, A. H., Henderson, G. B., Bacchi, C. J. \& Cerami, A. (1987). In vivo effects of difluoromethylornithine on trypanothione and polyamine levels in bloodstream forms of Trypanosoma brucei. Mol Biochem Parasitol 24, 185-191.

George, P. (1953). Intermediate compound formation with peroxidase and strong oxidizing agents. $J$ Biol Chem 201, 413-434.

Griffiths, J. L. \& Shoesmith, J. G. (1977). The enhancement of the bacteriocidal effect of oxygen on obligate anaerobes by sodium thioglycollate. Proc Soc Gen Microbiol 4, 45.

Halliwell, B. \& Gutteridge, J. M. C. (1989). Free Radicals in Biology and Medicine. Oxford: Oxford University Press. 
Kitchener, K. R., Meshnick, S. R., Fairfield, A. S. \& Wang, C. C. (1984). An iron-containing superoxide dismutase in Tritrichomorias foetus. Mol Biochem Parasitol 12, 95-99.

Lawrence, R. A. \& Burk, R. F. (1976). Glutathione peroxidase activity in selenium-deficient rat liver. Biochem Biopbys Res Commun 71, 952-958.

Lindmark, D. G. \& Müller, M. (1974). Superoxide dismutase in the anaerobic flagellates Tritrichomonas foetus and Monocercomonas spp. $J$ Biol Chem 249, 4634-4637.

Linstead, D. J. \& Bradley, S. (1988). The purification and properties of two soluble reduced nicotinamide: acceptor oxidoreductases from Trichomonas vaginalis. Mol Biochem Parasitol 27, 125-134.

Lloyd, D. \& Coombs, G. H. (1989). Aerotolerantly anaerobic protozoa: some unsolved problems. In Biochemistry and Molecular Biology of Anaerobic Protozoa, pp. 267-286. Edited by D. Lloyd, G. H. Coombs \& T. A. Paget. Chur, Switzerland: Harwood Academic.

Lloyd, D. \& Edwards, S. W. (1978). Electron transport pathways alternative to the main phosphorylating respiratory chain. In Functions of Alternative Oxidases, pp. 1-10. Edited by H. Degn, D. Lloyd \& G. C. Hill. Oxford: Pergamon.

Lloyd, D. \& Pedersen, J. Z. (1985). Metronidazole radical anion generation in Trichomonas vaginalis: oxygen quenching is enhanced in a drug-resistant strain. J Gen Microbiol 131, 87-92.

Lloyd, D., Williams, J., Yarlett, N. \& Williams, A. G. (1982). Oxygen affinities of the hydrogenosome-containing protozoa, Tritrichomonas foetus and Dasytricha ruminatium, and two aerobic protozo:a, determined by bacterial bioluminescence. I Gen Microbiol 128, $1019-1022$.

Lloyd, D., Ohnishi, T., Lindmark, D. G. \& Müller, M. (1983). Respiration of Tritrichomonas foetus. Wiad Parasizytol 29, 37-39.

Lloyd, D., Yarlett, N., Hillman, K., Paget, T. A., Ellis, J. E. \& Williams, A. G. (1989). Oxygen and aerotolerant protozoa: studits using non-invasive techniques. In Biochemistry and Molecular Biology of Anaerobic Protozoa, pp. 1-21. Edited by D. Lloyd, G. H. Coombs \& Г. A. Paget. Chur, Switzerland: Harwood Academic.

McCord, J. M. \& Fridovich, I. (1969). Superoxide dismutase: an enzymatic function for erythrocuprein (hemocuprein). J Biol Chem 244, 60496055 .

Meshnick, S. R. \& Eaton, J. W. (1983). Leishmanial superoxide dismutase: a possible target for chemotherapy. Biochem Biophys $\mathrm{R}_{t}$ Commun 102, 970-976.

Moreno, S. N. J. \& Docampo, R. (1985). Mechanism of toxicity of nitro compounds used in the chemotherapy of trichomoniasis. Environ Health Perspect 64, 199-208.
Morris, J.G. (1979). Nature of oxygen toxicity in anaerobic microorganisms. In Strategies of Microbial Life in Extreme Environments, pp. 149-162. Edited by M. Shiol. Berlin: Dahlem Konferenzen.

Müller, M. (1990). Biochemistry of Trichomonas vaginalis. In Trichomonads Parasitic in Humans, pp. 53-83. Edited by B. M. Honigberg. New York: Springer-Verlag.

Müller, M. \& Lindmark, D. G. (1978). Respiration of the hydrogenosomes of Tritrichomonas foetus. II. Effect of $\mathrm{CoA}$ on pyruvate oxidation. J Biol Chem 253, 1215-1218.

Müller, M., Meingassner, J. G., Miller, W. A. \& Ledger, W. J. (1980). Three metronidazole-resistant strains of Trichomonas vaginalis from the United States. Am J Obstet Gynecol 138, 808-812.

Paget, T. A. \& Lloyd, D. (1990). Trichomonas vaginalis requires traces of oxygen and high concentrations of carbon dioxide for optimal growth. Mol Biochem Parasitol 41, 65-72.

Rashad, A. L., Toffler, W. L., Wolf, R. N., Thornberg, K., Kirk, E. P., Ellis, G. \& Whitehead, W. E. (1992). Vaginal $p \mathrm{O}_{2}$ in healthy women and women infected with Trichomonas vaginalis: potential implications for metronidazole chemotherapy. Am J Obstet Gynecol 166, 620-624.

Smith, K., Thornton, J. M. \& Fairlamb, A. H. (1991). Trypanothione metabolism as a target for drug design: molecular modelling of trypanothione reductase. In Biochemical Protozoology, pp. 482-492. Edited by G. H. Coombs \& M. J. North. London: Taylor \& Francis.

Tannich, E., Bruchhaus, I., Walter, R. D. \& Horstmann, R. D. (1991). Pathogenic and non-pathogenic Entamoeba bistolytica: identification and molecular cloning of an iron-centre superoxide dismutase. Mol Biochem Parasitol 49, 61-72.

Thong, K-W. \& Coombs, G. H. (1987). Comparative study of ferredoxin-linked and oxygen metabolizing enzymes of trichomonads. Comp Biochem Physiol 87B, 637-641.

Trang, N. L., Meshnick, S. R., Kitchener, K. R., Eaton, J. W. \& Cerami, A. (1983). Iron-containing superoxide dismutase from Crithidia: purification, characterization and similarity to leishmanial and trypanosomal enzymes. $J$ Biol Chem 258, 125-130.

Wagner, G. \& Levin, R. (1978). Oxygen tension of the vaginal surface during sexual stimulation in the human. Fertil Steril $\mathbf{3 0}$, 29-40.

Yarlett, N., Yarlett, N. C. \& Lloyd, D. (1986). Metronidazoleresistant clinical isolates of Tricbomonas vaginalis have lowered oxygen affinities. Mol Biochem Parasitol 14, 29-40.

Received 28 February 1994; revised 29 April 1994; accepted 11 May 1994. 